\title{
DA FORMAÇÃO SAPIENCIAL À TRANSFORMAÇÃO PROFÉTICA: ESPIRITUALIDADE, PAIDEIA E CONTEMPORANEIDADE EM D. TIMÓTEO AMOROSO
}

Luciano Costa Santos*

\begin{abstract}
RESUMO
Com base no itinerário existencial do abade, pensador e escritor D. Timóteo Amoroso Anastácio, a partir das experiências inaugurais que contribuem para a sua formação humana e intelectual, busca-se articular neste artigo os principais núcleos conceptivos subjacentes a seu pensamento e obra. De tal reconstituição analítica destacam-se as vertentes sapiencial e profética de sua espiritualidade, cuja composição promove um fecundo diálogo entre a memória do eterno inscrita na tradição monástica e o projeto de emancipação da modernidade, gerando assim uma inaudita versão "transmoderna" do cristianismo, simultaneamente herdeira de milenar tradição sapiencial, atualizada com os movimentos históricos de libertação e enraizada na cultura local de matriz popular, configurando uma nova paideia apta a responder aos principais desafios formativos postos na contemporaneidade.
\end{abstract}

Palavras-chave: Experiência. Formação. Espiritualidade. Paideia. Contemporaneidade.

\begin{abstract}
FROM SAPIENTIAL EDUCATION TO PROPHETIC TRANSFORMATION: SPIRITUALITY, PAIDEIA AND CONTEMPORANEITY IN D. TIMÓTEO AMOROSO

Based on the existential journey of the abbot, thinker and writer D. Timóteo Amoroso Anastácio, from the inaugural experiences that contribute to his human and intellectual formation, seeks to articulate in this article the main ideas core underlying his thought and work. From this analytical reconstitution, stand up the wise and prophetic aspects of his spirituality, whose composition promotes a fruitful dialogue between the eternal memory inscribed in the monastic tradition and the emancipatory project of modernity, generating an unprecedented version "transmodern" of Christianity, simultaneously heir of ancient wisdom tradition, updated with the historical movements of liberation and rooted in the local culture of popular matrix, setting a new paideia able to respond to the main educational challenges of contemporary times.
\end{abstract}

Keywords: Experience. Formation. Spirituality. Paideia. Contemporaneity.

\footnotetext{
* Doutor em Filosofia pela Pontifícia Universidade Católica do Rio Grande do Sul (PUCRS). Professor do Departamento de Educação do Campus I da Universidade do Estado da Bahia (UNEB) e do Programa de Pós-Graduação em Educação e Contemporaneidade (PPGEDUC-UNEB). Email: lucostasantos1@gmail.com
} 


\title{
RESUMEN
}

\section{DE LA FORMACIÓN SAPIENCIAL A LA TRANSFORMACIÓN PROFÉTICA: ESPIRITUALIDAD, PAIDEIA E CONTEMPORANEIDAD EN D. TIMÓTEO AMOROSO}

Basado en el itinerario existencial del abad, pensador y escritor D. Timóteo Amoroso Anastácio, desde las experiencias inaugurales que contribuyen a su formación humana e intelectual, este texto articula las ideas principales subyacentes a su pensamiento y trabajo. De esta reconstitución analítica se destacan los aspectos sapiencial y profético de su espiritualidad, cuya composición promueve un diálogo fructífero entre la memoria eterna inscrita en la tradición monástica y el proyecto emancipatorio de la modernidad, lo que genera una versión "transmoderna" del cristianismo, sin precedentes, heredera de la antigua tradición de la sabiduría, actualizada con los movimientos históricos de liberación y arraigada en la cultura local de matriz popular, constituyendo una nueva paideia capaz de responder a los principales desafíos educacionales de los tiempos contemporáneos.

Palabras claves: Experiencia. Formación. Espiritualidad. Paideia. Contemporaneidad.

\author{
Para José Antônio Saja \\ "Profeta é aquele que faz nascer." \\ (D. Timóteo Amoroso)
}

\section{O itinerário formativo de D. Timóteo Amoroso}

Com o nome civil de Luís Antônio Amoroso Anastácio, D. Timóteo nasceu para o mundo em Barbacena/MG, em 1910, ano em que a feérica aparição do cometa Halley lhe comunica uma primeira e remota experiência do mistério numinoso: ${ }^{1}$

Ah! Mas isso é uma marca tremenda que eu tenho porque nasci no ano do cometa Halley e tenho no meu fundo assim mais místico, naquilo que há de mais elementar, menos racional, não digo que seja irracional, mas extra racional, que há em mim, há o cometa Halley na linha do horizonte, ao poente, ocupando todo o céu, banhado no sangue do sol, e ele próprio é luminoso, isso é, uma constelação psíquica para mim. (ANASTÁCIO, 1989, p. 4).

O menino mineiro é despertado para o senso do mistério por um astro incandescente e, desde então, o céu, com a sua aura de transcendência, passa a lhe atrair como uma espécie de pátria mítica originária. Em sua narrativa sobre o Halley, chama

1 Sobre o conceito de numinoso como base da experiência religiosa, ver Otto (2007). atenção que D. Timóteo Amoroso afirma tratar-se de uma experiência "extrarracional", mas não "irracional", frisando assim o contraste sem contradição, e mesmo a solidariedade de fundo entre as vias afetiva e racional de conhecimento. A visão extática do Astro-arquétipo dilata o horizonte de compreensão da razão, mas não a nega em seu modus operandi. Trata-se de "fundo místico", não de mistificação. Dotado de fina sensibilidade e vivaz imaginação, poeta bissexto de mão cheia, amigo de escritores e artistas de primeira grandeza, um dos fios que atravessa a obra de D. Timóteo Amoroso é a consideração da linguagem simbólica-artística como instância primordial de acesso ao sentido dos fenômenos, alinhando-se aqui a uma fecunda vertente do pensamento contemporâneo que soube tirar as mais vigorosas consequências ontológicas da fenomenologia da experiência estética:

Foi principalmente o Ocidente, com o seu sonho cartesiano de lucidez angélica, quem mais perdeu o contato com os símbolos, tentando uma civiliza- 
ção de ideias e uma clara ciência das coisas. Mas esqueceu-se de que não basta conhecer sobre as coisas. Precisamos, sobretudo, de apreendê-las a elas mesmas, numa intuição que vai além do processo discursivo. O homem, para ficar são, precisa olhar, ouvir, deixar a realidade escorrer para o seu coração e a sua mente. [...] Com esta separação que nos desmana das coisas, perdemos os símbolos da humanidade. Apaga-se-nos uma estrela de guia, enquanto a surda aspiração das coisas para o seu Pastor (lembram-se do dito de Heidegger sobre o homem, "pastor do ser'?) esbarra em nossa indiferença desmemoriada. (ANASTÁCIO, 1990, p. 78-79, grifo do autor).

Tal compreensão estética se aplica à linguagem simbólica da Liturgia, sistema de ritos constituído por textos, imagens, gestos, cantos e vestuários, que guarda e transmite o legado espiritual da tradição religiosa. Na década de 1940, já monge do Mosteiro beneditino do Rio de Janeiro, D. Timóteo Amoroso acompanha a vibrante renovação litúrgica comandada pelo confrade D. Martinho Michler, especialista em Liturgia da Ação Católica, ${ }^{2}$ que aproxima do povo leigo a linguagem do culto e atrai às missas do Mosteiro uma cativa audiência de intelectuais e artistas, como Murilo Mendes e Jorge de Lima. A Liturgia é a poesia da fé e, justamente por transitar com igual desenvoltura entre os campos artístico e religioso, D. Timóteo Amoroso receberia, na década de 1950, o encargo de assessorar a Pastoral de Liturgia da Conferência Nacional dos Bispos do Brasil (CNBB).

Outro evento-experiência que marcou o itinerário de D. Timóteo Amoroso é a formação religiosa recebida em família, em especial da mãe, devota e culta, responsável em boa medida por sua precoce decisão de entrar para o Seminário com apenas doze anos de idade, mesmo enfrentando a razoável resistência paterna:

Minha mãe, que me marcou muito, é de uma família mineira tradicional que tem suas raízes em Ouro Preto e Congonhas do Campo. Ela foi criada numa fazenda, com um espírito extremamente religioso. Isso marcou muito a todos nós, tanto que quando eu era pequeno exprimi o desejo de ser padre e por isso eu lutei. (ANASTÁCIO, 1989, p. 2).

2 Fundada em 1935 pelo Cardeal D. Sebastião Leme, a Ação Católica Brasileira foi um movimento organizado pela Igreja para formar quadros leigos a serviço da cristianização da sociedade brasileira em meio ao contexto de modernização da época.
Distante do irrequieto litoral, resguardada por muralhas de montanhas e guardando em seu coração o vasto sertão, terra do gênio místico de Aleijadinho e Guimarães Rosa, a poucas regiões do Brasil foi dada, como às Minas, tanta pachorra para permitir ao catolicismo ibérico deitar fundas raízes, assim como tão apropriada moldura para o cultivo da vida religiosa institucional. É um tal catolicismo, ascético, moralizante e, no caso de Luís Antônio, enternecido por profundos laços familiares de afeto, que o menino recebe na veia e, com farta provisão de cultura clássica greco-latina, ilustra no Seminário de Mariana. Depois de quatro anos de formação regular, porém, nova experiência vem interromper o seu ciclo de estudos para o sacerdócio:

Acho que foi o acordar da sexualidade, foi uma explosão da adolescência. Eu senti no Seminário as veias intumescerem e aquela inquietação, aquela angústia da descoberta da sexualidade que na época da infância não produz um impacto. Então achei o seguinte: eu fui feito para casar, estou no lugar errado. (ANASTÁCIO, 1989, p. 4).

Longe de reduzir-se a episódio pontual associado às alterações hormonais da adolescência, a irrupção da sexualidade propicia a Luís Antônio a "descoberta" de uma dimensão nuclear da existência a que já não teria como descurar, qualquer que fosse o modo de vida, casado ou celibatário, ao qual estivesse vocacionado. Como o clarão da transcendência no rastro do Halley e o senso da Presença divina haurido no seio familiar, Eros faz sua entrada definitiva na consciência de Luís Antônio, contribuindo para estruturar sua personalidade, integrando-se a sua compreensão de si mesmo e do mundo. Anos mais tarde, ao deparar-se com jovens monges em crise vocacional devido ao aflorar da sexualidade, o diretor de noviços $\mathrm{D}$. Timóteo Amoroso lhes previne que, embora o fenômeno comporte delicado desafio à vida religiosa, somente haveria problema propriamente dito em situação inversa, pois um monge que não vivesse de modo integrado a sua sexualidade não poderia ser um orientador espiritual confiável, ao privar-se de aspecto essencial de sua humanidade.

Com a sólida cultura de Humanidades adquirida no Seminário, o estudante Luís Antônio ingressa sem dificuldade na Faculdade de Direito de Belo 
Horizonte, tornando-se colega de futuras figuras públicas eminentes, como Tancredo Neves e Magalhães Pinto. À escolha do Direito impele-o generoso pendor de serviço social, o que, nessa altura, antes significa a disposição altruísta de levar a Justiça a quem dela mais careça, que o projeto de trabalhar pela transformação das estruturas político-sociais reprodutoras de injustiça em ampla escala.

Mal começara a cursar Direito, eis que, em outubro de 1930, estoura a Revolução comandada por Getúlio Vargas, que depõe o presidente Washington Luís, representante da oligarquia latifundiária café-com-leite, e institui uma série de mudanças que fincam as bases do moderno Estado brasileiro, como a Consolidação das Leis do Trabalho (CLT), salário mínimo, voto secreto, voto feminino, implementação da indústria nacional, dentre outras. Eletrizado pelo discurso liberal que galvanizava a juventude, Luís Antônio alista-se, com outros colegas, no exército revolucionário e chega a arriscar a vida em campo de batalha. A experiência revolucionária revoluciona a consciência do jovem universitário. Doravante, compreende que não há como assegurar os direitos dos cidadãos "pequenos" sem enfrentar o poder da minoria que os exclui em favor dos próprios privilégios; não há, portanto, justiça social sem luta política: "A revolução de 1930 acordou em mim a dimensão política. Foi uma campanha belíssima!” (TAVARES, 1995, p. 156).

Após formar-se advogado, Luís Antônio se estabelece no Rio de Janeiro em busca de maiores oportunidades profissionais, passando a trabalhar como secretário do primo Alceu Amoroso Lima (Tristão de Ataíde), famoso crítico literário com quem se correspondia há tempo e de cujas obras era leitor assíduo. A convivência cotidiana com Alceu, cuja correspondência com intelectuais das mais diversas procedências, do Brasil e de fora, lhe cabia organizar, deu a Luís Antônio a oportunidade de conhecer in vivo um espírito universal da mais alta estatura humana e intelectual. Convertido ao Catolicismo em fins da década de 1920, após intenso debate epistolar com o líder católico "reacionário" Jackson de Figueiredo, ${ }^{3}$ Alceu Amoroso

\footnotetext{
3 Advogado e escritor sergipano (1891-1928) convertido ao Catolicismo após uma juventude anticlerical, torna-se o maior líder leigo da "reação" católica às ideias modernas comandada pelo Cardeal do Rio de Janeiro D. Sebastião Leme, e prezava designar a si mesmo de "reacionário".
}

Lima vem a suceder a este na direção do Centro D. Vidal e da Revista A Ordem, órgãos da intelligentsia católica concebidos como reação às transformações modernas em curso no Brasil. De espírito dialógico, aberto, equilibrado, Alceu termina por empunhar a bandeira da democracia e dos princípios republicanos, aproxima-se do socialismo de inspiração cristã e dos movimentos de libertação social, acompanha com simpatia os desdobramentos da estética modernista de 1922, promove, enfim, fecunda conciliação do pensamento católico com os movimentos modernos de emancipação intelectual, estética, social e política, saltando para fora da antinomia até então vigente entre modernidade (antirreligiosa) e catolicismo (antimoderno) em que se debatia boa parte da intelectualidade nacional.

No Rio de Janeiro, Luís Antônio torna-se vizinho da família Hungria, egressa da cidadezinha mineira de Rio Pomba, que lhe reservaria um de seus mais decisivos encontros. Ao ser apresentado à jovem Jenny Hungria, quando esta ainda não contava dezoito anos, o moço galanteador percebe afinal estar diante da mulher de sua vida. A paixão é correspondida, logo evolui em namoro e presto se casam. Poucos meses depois de casados e "muito felizes" em seu idílio, Jenny apresenta sintomas de tuberculose em estado avançado. A luta com a doença prolonga-se por cerca de três anos, nos quais o jovem esposo prodigaliza toda sorte de cuidados para minorar o sofrimento da amada. Por fim, a doença chega ao estado terminal e Jenny morre "em paz", velada pelo amado, após este providenciar-lhe a extrema unção:

A descoberta do amor compromete a gente definitivamente, porque o amor, ao mesmo tempo que se concretiza num dom, é aberto a todos. Ele não sofre restrição, ele não discrimina, é contra a essência do amor, o amor é dom, é saída de si pelo outro como tal. Considero que essa etapa de minha vida ajudou a quebrar o egoísmo espontâneo que a gente tem, isso é normal no homem, a gente se defende, a gente desenvolve estruturas de egoísmo, de fechamento, de segurança contra o outro, e aquilo rompeu tudo isso porque eu tive a graça de me dar totalmente a ela. (ANASTÁCIO, 1990, p. 9).

Passado o trágico desenlace, o viúvo Luís Antônio aos poucos retoma a rotina profissional no Rio de Janeiro, atuando como advogado na área 
de Direito Civil. Quase dois anos mais tarde, em 1940, é convidado por colegas a passar um retiro de carnaval no Mosteiro de São Bento. Após alguma hesitação, topa. E a densa atmosfera de recolhimento e oração o atinge em cheio. Embora "jamais" pensasse em voltar para a vida religiosa, uma nova epifania existencial o conduz à mais radical virada de sua vida: "Aí fiquei tocado pela coisa. Uma coisa muito misteriosa, meio indescritível, porque a experiência religiosa é suprarracional. Fiquei assim transido. Voltei para casa e decidi." (TAVARES, 1995, p. 171). Entrega as causas pendentes a colegas advogados e, em plena Quaresma, ingressa na vida monástica.

Formado pelas experiências de mistério, poesia, Deus, sexualidade, revolução, amor, morte, Luís Antônio afinal estava pronto para deixar nascer de dentro de si D. Timóteo Amoroso.

\section{A vertente sapiencial da espiritualidade}

Admitido à vida religiosa, o noviço beneditino segue a disciplina canônica: oração litúrgica, leitura bíblica, missa, estudos, tarefas comunitárias, segundo o lema milenar do ora et labora. Consagra-se ao recolhimento espiritual. Este consiste no paciente exercício de recentramento do próprio eu em torno do mistério da Presença e da Palavra divinas, a partir de cuja inspiração toda a vida ganha novo sentido:

A visão que a palavra de Deus nos dá do homem não se limita a reconhecer nele a dimensão de 'domínio do mundo e senhor da Criação', bem como a dimensão política, isto é, a vocação para conviver, mas inclui a dimensão da adoração. As duas primeiras são aceitas e favorecidas pela civilização secular dos nossos tempos. Mas esta esquece a dimensão 'religiosa', que, no entanto, é tão essencial ao homem, como as outras, e é mesmo a primeira, da qual brotam as demais. Ignorá-la é truncar o homem e levá-lo a fechar-se em si mesmo e a todas as consequências e desordens que ameaçam a civilização atual com a catástrofe. (ANASTÁCIO, 1990, p. 115, grifo do autor).

Apesar de consagrada a uma dimensão primordial do humano, da qual promana o sentido para as demais, a vida monástica comporta uma excepcio- nalidade já sugerida em seu nome, pois "monge" deriva de monachus, que significa único, solitário. De fato, o monaquismo cristão teve início por volta do século II desta era, quando homens e mulheres do norte da África se retiravam ao deserto para devotar-se à vida de oração e autoconhecimento, sendo também chamados de "anacoretas", isto é, "separados da vida social". Desenvolvendo extraordinária perícia no conhecimento e tratamento das afecções da alma, eles/elas atraíam seguidores em busca de condução espiritual, passando a ser chamados de "pais/mães" - ou ainda "terapeutas" - do deserto. Com a estabilização de comunidades sob a autoridade de um "Pai/Mãe" (abade/ abadessa) e uma Regra de conduta, surgem mais tarde os mosteiros cenobitas, dos quais o fundado por São Bento em Montecassino, no século VI, é o primeiro no Ocidente. O paradoxo do monge é que, quanto mais se distancia da vida ordinária entre os humanos, mais tende a se aproximar deles; quanto mais recolhe-se a si mesmo, tanto mais se abre em "solidariedade e participação na luta dos homens por liberdade, justiça, alegria.” (ANASTÁCIO; SAJA, 1990, p. 24).

Em última instância, a "visão de Deus" constitui a própria razão de ser da vocação monástica. Em linguagem hodierna, dir-se-ia que o monge é o "especialista na busca de Deus". ${ }^{4}$ Por influência de uma tradição grega de acento marcadamente intelectual, a vida monástica passa então a ser concebida como "vida contemplativa" (biós theoretikós), votada à visão ou saber (de Deus) pelo saber, o que remonta ao ideal do "sábio" autárquico liberto dos labores materiais reservados aos escravos. Tal ideal, sem apoio na espiritualidade cristã primitiva radicada no Evangelho, ressoa uma antropologia dualista de viés platônico, na qual "a alma aspira à fuga do mundo e à evasão do sensível para se absorver na contemplação do inteligível, e contemplar na sua própria essência a luz divina."

4 Assim o atesta D. Timóteo Amoroso: "Quem deseja se especializar em Eletrônica ou Biologia, ou qualquer outro ramo de pesquisa científica e tecnológica, procura um Centro afamado e aí se presta a todas as exigências da pesquisa, e sofre o desafio do lado enigmático e do mistério do objeto procurado, e do modo de conhecimento que permite atingi-lo. Assim há também homens e mulheres que 'especializam' na Busca de Deus. Numa sociedade pluralista e democrática, têm direito à consideração e ao respeito e, ainda, ao direito de comunicar aos outros o fruto de seu trabalho." (ANASTÁCIO; SAJA, 1990, p. 24). 
(ANASTÁCIO, 1990, p. 113) Repondo a "vida contemplativa" no leito semítico do Evangelho, D. Timóteo Amoroso frisa que o alvo da contemplação cristã não é "o Deus dos filósofos e dos sábios, mas o Deus de Jesus Cristo." (ANASTÁCIO, 1990, p. 14). Aqui, conhecer a Deus - no sentido bíblico do verbo - não consiste propriamente em "ver" a Deus como Ser absoluto, mas em viver em Cristo - Deus-Humano - em todas as ações e relações da vida, inclusive as mais cotidianas.

Prospectando o sentido de cada Pessoa que participa do "Deus Trindade", D. Timóteo Amoroso encontra uma sugestiva correspondência fenomenológica com outras três dimensões ou vetores da pessoa humana, criada, segundo a Revelação, à imagem e semelhança do Deus Trino: as dimensões "para cima" (transcendência), "horizontal" (relação inter-humana) e "para dentro" (interioridade), correspondentes ao Pai, ao Filho e ao Espírito Santo, respectivamente:

O ser humano vive em três dimensões: uma para cima, uma horizontal e uma para dentro. Nessa dimensão para cima ele encontra o Deus Pai, não esse pai que a psicologia mostra que o adolescente tem que matar para ele poder crescer, mas uma paternidade divina que não abafa o ser humano, pelo contrário, quer ajudá-lo a desabrochar ao máximo suas potencialidades de atingir a natureza humana e não ficar como o filhinho humilhado e manipulado eternamente, que é o Deus Todo poderoso de muita gente, do qual eu sou ateu. Depois o Deus Filho, que é o Deus horizontal, o Deus do humanismo, o Deus da utopia de uma sociedade fraterna, utopia que não é um sonho irrealizável, mas é um sonho praticável e acaba, sei lá como. E o Deus da interioridade, que é o da profundeza do ser, da pessoa de cada um, é o Espírito Santo, é um Deus Espírito, Aquele que sopra como Ele quer, que agrega, que une. É um Deus pluralista, porque não é um Deus monolítico, é um Deus da unidade, mas não da uniformidade. Então, é esse Deus que eu adoro e que gostaria que as pessoas tentassem conhecer e, junto com os ateus, eu rejeito o Deus tapa-buraco, o Deus da magia, o Deus déspota, caprichoso e sádico, para amar esse Deus que é meu Pai. (ANASTÁCIO, 1989, p. 25-26).

Sob a regência dessa antropologia teológica tripartite, a vida monástica compreende, portanto, adoração da transcendência divina consubstanciada no mistério de sua Presença e na Revelação de sua Palavra; relação de amor com a pessoa do próximo considerada não como objeto de desejo, mas chamado à entrega incondicional de si; e introspecção ou conhecimento de si mesmo à luz do Espírito divino que, segundo Santo Agostinho, é interior intimo meo, isto é, "mais íntimo a mim do que eu mesmo".

Embora não visasse o cultivo do saber como ideal em si mesmo, ao modo grego, também é certo que o monaquismo cristão ensejou a produção de conhecimento nas mais diversas áreas, exercendo marcante papel civilizador no Ocidente, sobretudo na Europa medieval. Quer se tenha em vista os conhecimentos de medicina, farmácia e botânica requeridos para o cuidado com a saúde dos hóspedes, ou os projetos arquitetônicos das construções em estilo românico e gótico, a música gregoriana, as esculturas e afrescos das igrejas, as iluminuras e gravuras dos manuscritos, a cópia e tradução de inúmeros clássicos da literatura greco-latina; ou ainda a recapitulação, na formação dos monges, do conjunto de ciências da educação antiga constantes no Trivium (Lógica, Gramática, Retórica) e Quadrivium (Aritmética, Geometria, Música, Astronomia); ou, muito especialmente, a possante produção filosófico-teológica que inclui luminares do vulto de $\mathrm{S}$. Anselmo e S. Tomás de Aquino - o fato é que os mosteiros não somente foram escolas de fé reservadas ao recolhimento espiritual, como propiciaram a incubação de um caldo de cultura com poderosa influência para além de seus muros, inclusive favorecendo a fundação da Universidade em plena Idade Média. Como atesta D. Timóteo Amoroso, já então do alto de seus oitenta anos, no discurso de agradecimento por ocasião da outorga do título de Doutor Honoris Causa pela Universidade Federal da Bahia, em 1990:

É evidente o laço que existiu entre as origens cassinenses, ${ }^{5}$ entre o mosteiro e os campos do saber, que constituem a missão ensinante da Universidade - ciências exatas, ciências do homem, artes e letras, tudo isso coroado por um saber superior, uma 'filosofia' do homem, da vida, da sociedade, orientando todos os 'disiecta membra' do conhecimento para uma unidade transcendente. (ANASTÁCIO; SAJA, 1990, p. 21, grifo do autor).

5 Referência ao Mosteiro de Montecassino, fundado no século VI por São Bento de Núrsia e precursor da tradição dos mosteiros cenobitas no Ocidente. 
Ora, o "saber superior" que coroa e coordena os múltiplos saberes produzidos na Universidade em vista de sua "unidade transcendente" corresponde, em contexto medieval, ao que na Antiguidade Clássica se chamava paideia, ou seja, o ideal de formação humana que deveria inspirar a conduta dos cidadãos em seus tantos âmbitos de atuação. Por diversas que sejam as competências nela implicadas, a paideia concerne antes à ordem sapiencial que à do saber, e comunica um sentido do bem, do vero e do belo cuja adesão forma o que há de propriamente humano no ser humano.

Assim, no conceito antigo, toda educação é orientada para a formação do homem adulto, para a perfeita 'humanização' do homem. Bem o perceberam Cícero e Varrão, que traduzem paideia por humanitas. Não se trata de jogar uma educação do homem contra o técnico, como foi posteriormente a posição da pedagogia helenística, mas de conduzir toda a atividade educativa, salvo a autonomia e a especificidade de cada ramo do saber, a buscar um ideal pessoal, em que a pessoa humana se reencontre como princípio e como fim, e do qual seja também cada aluno co-criador. (ANASTÁCIO; SAJA, 1990, p. 22, grifo do autor) ${ }^{6}$

Herdeira da cultura clássica, a tradição monástica ressignifica a paideia grega a partir da fé cristã, o que fica evidente na fala de D. Timóteo Amoroso ao inscrever a pessoa como "princípio" e "fim" da formação humana. Como vimos, a categoria de pessoa radica no campo teológico e designa as entidades que participam do Ser divino e subsistem em si mesmas na relação de doação de umas às outras. Deus é, pois, uno e, ao mesmo tempo, diverso em cada uma de suas pessoas; é comunidade de pessoas. Transpondo-se ao ser humano - criado à imagem de Deus -, por analogia "pessoa" passa a

6 Sobre o sentido grego de paideia, afirma Werner Jaeger (1989, p. 10-11) em seu clássico dedicado ao tema: "O princípio espiritual dos Gregos não é o individualismo, mas o 'humanismo' para usar a palavra no seu sentido clássico e originário. Significou a educação do Homem de acordo com a verdadeira forma humana, com o seu autêntico ser. Tal é a genuína paideia grega, considerada modelo por um homem de estado romano. Não brota do individual, mas da ideia. Acima do homem como ser gregário ou como suposto $e u$ autônomo, ergue-se o Homem como ideia. A ela aspiraram os educadores gregos, bem como os poetas, artistas e filósofos. Ora, o Homem, considerado na sua ideia, significa a imagem do homem genérico na sua validade universal e normativa. Como vimos, a essência da educação consiste na modelagem dos indivíduos pela norma da comunidade." designar o ser espiritual, isto é, livre e consciente, único, dotado de dignidade absoluta - porque fim em si mesmo - e que se realiza na sujeição a valores transcendentes e na relação de uns com os outros. À imagem do Deus trino, o ser humano se constitui em comunidade; reduzida a si mesma, portanto, a pessoa sequer chega a ser, como corrobora $\mathrm{D}$. Timóteo Amoroso, citando Padre Piva:

Pessoa diz abertura a alguém. No encontro se dá conhecimento ou reconhecimento recíproco, e com isso o autoconhecimento e daí o crescimento humano recíproco. O desenvolvimento da pessoa humana conduz sempre 'a um descentramento de si em relação aos outros; o nosso centro humano se combina com outros centros humanos sem dissolver, sem se perder: eis o amor.' (ANASTÁCIO, 1990, p. 98).

Se qualquer um de seus aspectos é suprimido, a integridade da pessoa periga desfigurar-se: sem liberdade e consciência, se escraviza ou aliena; negada em sua singularidade, esvazia-se do mistério mais profundo; sem dignidade, é privada do valor inexcedível que a distingue acima de todas as outras criaturas; fechada à transcendência e à relação com os outros, insula-se em si mesma até estiolar-se. Mencionando a passagem em que Jesus propõe ao jovem rico uma radical mudança de vida, em Mateus 19, 21: "Se queres ser perfeito, vai, vende tudo o que possuis e dá aos pobres, e terás um tesouro nos céus." (A BÍBLIA..., 1995, p. 1875), D. Timóteo Amoroso releva o respeito dialogal do Cristo à liberdade do interlocutor - portanto, ao seu estatuto de pessoa -, contrastando-o com a manipulação das consciências operante no atual contexto de massificação midiática:

Por ser livre, só a pessoa humana dialoga, e isto é essencial à estrutura da comunicação entre os homens, ainda que o diálogo tome as proporções gigantescas que a tecnologia oferece. O que está acontecendo no mundo da comunicação - e isto com terríveis consequências para a educação - não é um diálogo, como devia ser. É, antes, uma polêmica (uma guerra!) em que o propagandista quer vencer a gente, para nos convencer, dominar e anexar. O que aí está em jogo não é o puro valor da verdade, mas a intervenção de uma força brutal que se impõe e coloniza. Tão diferente, a ação do Cristo no Evangelho! Ele, sem dúvida, propõe uma opção existencial absoluta, mas com que respeito e delicadeza: 'se queres...', e isto 
através de atos gratuitos e criadores, que apelam para a espontaneidade e para o que há de mais pessoal no interlocutor. Cristo assume o risco de confiança e acorda no que o escuta aquele centro autônomo e original da pessoa. (ANASTÁCIO, 1990, p. 40, grifo do autor).

Não há singularidade pessoal sem autonomia de consciência: quem não pensa e decide por sua conta, não tem como ser si mesmo. Depois de muita controvérsia histórica, tal enlace dialógico de liberdade e graça, fé e razão, terminou por prevalecer na tradição da Igreja e, para tanto, jogou papel decisivo a posição assumida, entre os séculos II e V a.D., por pensadores proeminentes egressos da cultura greco-latina e convertidos à fé cristã, os chamados "Pais da Igreja", cuja filosofia é conhecida como "patrística". Entre os extremos simétricos do racionalismo e fideísmo, que, respectivamente, presumem a suficiência da razão e da fé como vias de acesso à verdade, bem como sua suposta incompatibilidade, o pensamento patrístico hegemônico sustenta a unidade na diversidade de fé e razão. Santo Agostinho, mestre maior da patrística, o resume de modo lapidar, afirmando que é preciso crer para compreender, e compreender para crer. Nesta perspectiva conciliadora, a fé revela mistérios que a razão não teria como vislumbrar por si mesma; e a razão permite à fé compreender em profundidade os seus mistérios, além de preveni-la contra o perigo do fanatismo. Aqui, tal é o papel jogado pela razão crítica que um ateísmo purgativo, a prevenir contra capciosas ilusões religiosas, pode ser considerado como passagem obrigatória ao amadurecimento da própria fé: "Grande parte do ateísmo do mundo de hoje, no fundo é uma grande fome do Deus verdadeiro, do Deus vivo que se exprime por uma recusa de todo ídolo e de toda concepção mágica de Deus. O homem moderno não pode aceitar esse Deus." (ANASTÁCIO, 1989, p. 24).

Erudito de cultura universal, com sólida formação acadêmica, dotado de vigor reflexivo e apurado senso crítico (como se verá adiante), D. Timóteo Amoroso é um humanista cristão na melhor linhagem patrística, e encarna à larga a conciliação de fé e razão, batendo-se pelo direito de ambas atuarem em seus respectivos campos.

No período em que permanece no Mosteiro do Rio de Janeiro, de 1940 a 1965, a vocação monásti- ca de D. Timóteo Amoroso amadurece em ambiente espiritual de profundo recolhimento e harmonioso diálogo de fé e razão: cumpre os estudos filosóficos e teológicos para o sacerdócio, pesquisa nas fontes da espiritualidade monástica, ensina Latim no Colégio São Bento, participa de (e prega) retiros, frequenta o Centro D. Vital, escreve para A Ordem, estreita amizade com grandes intelectuais católicos etc. Prevalece, então, em sua caminhada a vertente sapiencial da vida religiosa, que viceja a partir de paciente assimilação dos saberes, virtudes e valores hauridos na tradição, e comunica ao seu portador diferenciado uma aura de autoridade - de paternidade - espiritual, como se ele estivesse destinado a ser o guardião da memória da fé em torno da qual a comunidade se irmana.

A vida cristã é movida pelo mesmo Espírito Santo, mas através de duas mecânicas, vamos dizer assim. Uma mais sapiencial, que saboreia os valores, que inventaria os valores e, portanto, leva em grande consideração o passado, porque os valores são transmitidos, a tradição vem do passado. Isto é uma parte do espírito monástico. (TAVARES, 1995, p. 206).

\section{Para além do claustro}

Na pachorra do claustro, a paternidade espiritual de D. Timóteo Amoroso transparecia a cada dia aos olhos dos confrades. Antes, porém, de ser consagrada pela Ordem beneditina do Brasil, um novo encontro teria decisiva consequência em sua formação espiritual. No início da década de 1950, o então Bispo Auxiliar do Rio de Janeiro, D. Helder Câmara, organiza equipes de trabalho pastoral compostas por leigos, homens e mulheres, com arrojada inserção social em comunidades carentes da cidade. A ideia era ir além da assistência social filantrópica e contribuir para organizar as comunidades em vista do enfrentamento e superação das questões estruturais que as mantinham na penúria. Uma década antes do Concílio Vaticano II, D. Helder Câmara antevia um novo horizonte eclesial, que punha em segundo plano a pregação apologética para pôr-se a serviço das pessoas, sobretudo as socialmente mais vulneráveis, e anunciar-lhes a Boa Nova, que é "ficar livre da opressão, readquirir a liberdade, o poder de trabalhar, de ter uma velhice tranquila, de ter paz na família, de não estar ameaçado pela 
avareza e cobiça exacerbada do outro." (ANASTÁCIO, 1989, p. 10). D. Helder preparava, assim, o deslocamento paradigmático de uma Igreja da Reação, personificada no Cardeal Leme e em Jackson de Figueiredo, zelosa por proteger a sociedade contra a ameaça da secularização, para uma Igreja da Transformação, pneumatológica, ${ }^{7}$ aberta ao sopro renovador do Espírito, que começava a dialogar com movimentos de emancipação dos tempos modernos em favor da humanização da sociedade em seus vários setores. Solicitado, pelo cardeal do Rio, a providenciar um monge para colaborar na equipe de D. Hélder, o abade beneditino indica D. Timóteo Amoroso, e o engajamento semanal nos trabalhos pastorais terá sobre este o efeito de uma definitiva metanoia:

Com D. Helder Câmara a gente descobriu a dimensão coletiva da caridade, do amor, não apenas como transpessoal, mas também transpolítico, se assim se pode dizer. Não uma politização propriamente da fé, não se procurar uma nova tutela clerical da sociedade sendo esquerdista, mas é sentir a ignomínia da injustiça que está encravada nas estruturas da sociedade. Como se o egoísmo humano e a exploração do homem se tornassem estrutura, se fizessem instituição. Foi uma descoberta que eu, aí pelos anos 1950, fiz naquele convívio com D. Helder e as equipes de leigos que eram animadas por ele e que estavam refletindo uma nova organização da Igreja no Brasil. (ANASTÁCIO, 1989, p. 10).

Com D. Helder, D. Timóteo Amoroso descobre a outra vertente - profética - da vida religiosa. Enquanto a vertente sapiencial se enraíza na memória da tradição e resguarda o que nesta há de eterno e, pois, intransigível, o espírito de profecia é movido pela inesgotável fecundidade do Espírito, que atualiza a Revelação a partir dos momentos/movimentos de transformação da história, acolhendo o tempo como instante propício (kairós) ou acontecimento teofânico. Profeta é, portanto, aquele que ajuda a deixar o eterno vir à luz na história:

O profeta é aquele que está sempre antecipando a história e, portanto, movendo a história. Não como uma força mecânica, mas sugerindo, alimentando o ímpeto de criar aquela história que ele antecipa na sua visão futura. O profeta sempre choca, não porque gosta, mas porque está à frente. O profeta abala as

7 Referência ao Espírito Santo, designado Pneuma em grego. estruturas espessas, imobilizadas, que garantem segurança. As pessoas têm medo de ver, têm medo de criar, porque é mais confortável você ficar resguardado assim como uma criança no seio materno. É uma certa regressão uterina. Então o profeta é justamente aquele que faz nascer. Com os riscos do nascer, do enfrentar sem outra segurança que a certeza de que você está no caminho certo, que você é lançado para criar a vida. (TAVARES, 1995, p. 206).

Ciente, porém, de que a indomável vitalidade profética do Espírito não se restringe a nenhuma circunscrição confessional, e já começando a familiarizar-se com o pioneiro trabalho de transformação social levado a cabo por protagonistas sem fé religiosa, D. Timóteo Amoroso chega a propugnar o inusitado conceito de profetismo ateu, citando o filósofo Karl Marx como exemplo de sua particular admiração. ${ }^{8}$

Formado na instituição monástica, das frestas do claustro D. Timóteo Amoroso assiste às transformações que agitam o século XX. Aberto à visitação do novo, não ignora o reativo retraimento que tenta a vida monástica, na qual "todo mundo que fica muito preocupado com os valores do passado - enquanto 'passado', não enquanto 'valor' -, acaba ficando meio fixado nesse passado e, portanto, pouco inclinado à evolução da história." (TAVARES, 1994, p. 206, grifo do autor). Despertado por D. Helder Câmara, D. Timóteo compreende que, para não ensejar uma "regressão uterina" e confundir-se com reacionarismo, a vertente sapiencial precisa viver em tensão dialógica com a profética, assim como esta, sem a outra, periga perder substância e esvaziar-se em futurismo novidadeiro. Articulando as relações possíveis de sabedoria e profecia, tradição e renovação, eternidade e tempo, D. Timóteo Amoroso ensaia nova e luminosa tipologia, que pedimos licença para transcrever na íntegra:

$\mathrm{Na}$ sociedade de hoje, que está em grandes transformações, que produz grandes angústias também, porque a gente se sente inseguro, a gente pode tomar várias posições. Primeiro: posição de arcaísmo, se segurar na prisão do passado. Acaba em conservadorismo. Isso é muito comum de acontecer, inclusive dentro da Igreja. Uma Igreja que tem medo da história, tem medo dos desafios da história, então se fecha numa certa época que ela considera ideal e eri-

8 Cf. Tavares (1995). 
ge em norma. Que, naturalmente, vai coincidir com a época em que a Igreja tinha todos os privilégios, apoiada pelos reis, pelos príncipes. Há uma segunda tendência, oposta a esta, que é um futurismo completamente desligado de toda tradição. Uma espécie assim de sonho utópico, como se fosse criar tudo de novo. É, aliás, um modo de reagir a este mundo atual em mudanças, produzindo, inclusive, insegurança, insatisfação. Há também uma terceira atitude, que seria talvez modalidade desse futurismo. Chamemo-la de evasão. Por exemplo: a droga, o abuso do sexo. Um pouco nessa linha. Aquele movimento hippie dos anos 1960, que tinha valores muito grandes, mas que no princípio era medo ou horror da sociedade. Quer dizer, o julgamento da sociedade como perversa e o empenho de criar uma nova sociedade, mas de um modo muito alienado. Não interviam, por exemplo, na política. Não estavam presentes para lutar por essa sociedade para ela se transformar. Mas há uma quarta posição que eu chamaria de transfiguração. Não é uma arqueologia, uma reserva arcaica, nem é uma evasão, mas é o seguinte: é viver o presente e transfigurá-lo tendo em vista um projeto bem concebido. Inspirado pelos grandes valores da fé, da dignidade humana, do sentido da vida, mas um projeto que não tirava os pés da história. E vai justamente viver essa história, não de um modo puramente passivo. Não sofrer passivamente essa história, mas influir nela para que tome um novo rumo. (TAVARES, 1995, p. 207-208).

D. Timóteo Amoroso inspira-se no legado sapiencial da tradição sem enclausurar-se nesta; assume os projetos de emancipação da modernidade, mas não anui sua ruptura com a autoridade da tradição. Não é, portanto, antimoderno nem moderno tout court: ao forcejar um "novo rumo na história" a partir dos "grandes valores" da espiritualidade cristã, ao enraizar a energia transformadora da modernidade na memória do eterno, com a inesgotável jovialidade profética inscrita nesta, alcança ir além do próprio horizonte moderno e, nesse sentido, dir-se-ia antes - na falta de termo mais apropriado - "transmoderno". ${ }^{9}$ Com efeito, "apesar do pragmatismo que o domina, o mundo atual tem fome e sede de gratuidade e precisa da festa e dos velhos símbolos ancorados no fundo imemorial da espécie, onde jorram as fontes da jovialidade e das renascenças." (ANASTÁCIO, 1990, p. 119). Como todas as fases da história, a

9 Sobre o conceito de cristianismo transmoderno, ver Santos (2014). modernidade não se presta a simples aceitação ou rejeição, mas convida a acurado discernimento:

Ninguém nega que a adaptação ao mundo contém um risco enorme de modernismo inaceitável. Mas o mal não está em se adaptar, pois a Igreja tem a consciência de que sua missão é de se adaptar a um mundo no qual Deus encarnou em seu Filho Jesus Cristo e está presente nesta humanidade em franca mutação. Não se trata de entrar num processo de compromissos e facilidades, para vestir a fé ao gosto do dia. Trata-se, ao contrário, de levar a fé ao combate leal, procurando-se compreender e conhecer a si mesmo, em suas luzes e sombras, dentro da lealdade a si mesmo, mas, ao mesmo tempo, alargando os seus horizontes e avançando sem medo no coração da modernidade, ao encontro daquele 'que vem'. (ANASTÁCIO, 1990, p. 86-87).

Entre 1962 e 1965, por surpreendente iniciativa profética do Papa João XXIII, é convocado o Concílio ecumênico Vaticano II, que mobiliza autoridades eclesiásticas, teólogos(as) e leigos(as) no mundo inteiro visando atualizar o diálogo da Igreja Católica com o mundo contemporâneo, sendo responsável por uma das mais profundas renovações doutrinárias e institucionais em toda sua história. Colhido pela revolução conciliar, nos anos que se seguem D. Timóteo se aplicará em aprofundá-la em níveis reflexivo e prático, e assim resume o seu sentido:

Os teólogos de base estavam começando a rever tudo aquilo que depois foi desembocar no Concílio Vaticano II, que realmente deu uma nova postura à Igreja, sentindo-se não mais como um fim em si, uma sociedade perfeita, paralela à sociedade civil. O Concílio redescobriu o conceito de Povo de Deus, que é uma caminhada imprevisível. Então, a Igreja se descobre não como um fim em si, mas como uma estrutura a serviço do ser humano. Essa é que é a grande virada. (ANASTÁCIO, 1989, p. 13-14).

Em 1964, D. Timóteo Amoroso prega um retiro no Mosteiro de São Bento da Bahia e, pelo visto, causa muito boa impressão, pois um ano depois, com a morte do abade D. Plácido, o seu nome é aclamado pela comunidade para sucedê-lo. Fato pouco comum, tratando-se de um monge de outro Mosteiro. Chega a Salvador em plena convulsão dos anos 1960, com o Vaticano II no auge, um ano após o golpe militar, em meio a manifestações po- 
líticas contra o regime e à emergência de movimentos de juventude e do meio popular. Quando ainda no Mosteiro do Rio, seduzido pelo anticomunismo "católico" dos militares, por um momento é tentado a apoiar o golpe. Na Roma Negra, porém, terra de Jorge Amado, do Tropicalismo e de Todos os Santos, o filho de São Bento se livrará dos últimos laivos de conservadorismo e deixará desabrochar em cheio a sua veia profética.

\section{A vertente profética da espiritualidade}

Apenas dois meses depois de consagrado abade, em novembro de 1965, D. Timóteo Amoroso aproveita a celebração de uma missa de formatura universitária para promover, na igreja do Mosteiro de São Bento da Bahia, um gesto litúrgico que acalentava desde os tempos do Mosteiro do Rio: a apresentação da "Missa do Morro", composta em língua vernácula pelo confrade e amigo francês radicado no Brasil, D. Dominique, pessoa de grande talento artístico. Concebida com influência de elementos melódicos e rítmicos da música popular brasileira, colhidos pelo compositor nos morros cariocas com auxílio de Paulinho da Viola, a Missa é executada em plena igreja do Mosteiro com instrumentos percussivos afro-brasileiros usados no candomblé. A iniciativa de D. Timóteo, maturada após anos de rigorosa pesquisa litúrgica, se alinhava às orientações do Concílio Vaticano II no sentido da enculturação do Evangelho, com base no pressuposto teológico de que, sendo o Verbo de Deus encarnado, o Cristo não pode se confinar a uma cultura hegemônica, mas assumir a língua, jeitos e gestos de todos os povos da Terra.

O Concílio libertou a liturgia do imobilismo contraditório. A rígida unidade anterior deu lugar a formas flexíveis que, sem prejuízo do fundo inalienável dos ritos, tornam possível uma celebração encarnada. $\mathrm{O}$ gênio próprio do povo e da sua língua, o seu modo de expressão e de representação e a sua sensibilidade, a sua música, os seus instrumentos, o seu mundo intelectual - eis valores culturais chamados a contribuir ativamente para exprimir a vinda de Deus e a resposta do homem, na unidade simbólica do rito. A liturgia é, por definição, popular. Aí estão presentes os valores culturais expressos por essas puras e brasileiras melodias, acompanhadas de instrumentos populares, violões, atabaques, berimbaus que satisfazem a uma dupla exigência de fidelidade: fidelidade ao sagrado e fidelidade à cultura popular. (NETO et al., 1996, p. 37).

Escandalizada com o som de atabaques e berimbaus, parte expressiva da audiência, da alta classe média soteropolitana, reage à peça como "profanação" e promete nunca mais voltar ao Mosteiro. Em artigo publicado em seguida ao episódio, o escritor católico ultraconservador Gustavo Corção exproba a Missa como "macumba" litúrgica. Convicto da intrínseca "plasticidade" do monaquismo beneditino, "tão sensível ao mundo em que vive", D. Timóteo o entende como uma proposta apta "a entrar em intercâmbio com a cultura contemporânea de cada ciclo histórico.”, pois "Regra e Cultura não só não convivem separadas, mas mutuamente se influenciam, embora distintas." (ANASTÁCIO, 1990, p. 117). Em contrapartida ao repúdio da elite estrangeirada, o gesto sensível do abade atrai a cumplicidade de intelectuais e artistas enraizados no magma cultural da Boa Terra, como Jorge Amado, o músico Carlos Lacerda e o pintor Sante Scaldaferri, que não demoram em estreitar amizade com o monge poeta.

Nessa época, no dia 10 de fevereiro, dedicado a Santa Escolástica - irmã de São Bento e padroeira da Ordem beneditina -, a ialorixá Mãe Menininha do Gantois, cujo nome civil se chama Maria Escolástica, tinha por hábito celebrar a missa de aniversário no Mosteiro de São Bento. Ao se conhecerem, o abade e a ialorixá ligam-se por imediata simpatia e, desde então, inicia-se profícua amizade cultivada até a morte desta. D. Timóteo assim retrata a amiga:

O que mais me impressionava nela, sem falar da sua dignidade e de todas as qualidades humanas que lhe ornavam a vida, era a total dedicação, uma espécie de autoimolação sacrificial, a serviço da sua herança ancestral. Tudo o mais era aspirado por esse fundo imemorial e dele recebia ordenação e sentido. Isto revela a força mágica do seu caráter e personalidade. Mas não era um espectro do passado, prisioneiro de determinismos limitadores. Ao contrário, era uma pessoa viva, voltada para um futuro e, deste modo, marcada por um valor que jamais decaiu, uma finalidade assumida e querida, não imposta, num ato de liberdade e amor. Seu caráter era, assim - e isto me enche de admiração e respeito - um movimento constante para o alto e devotado a um 'mais ser', ao 
inacessível segredo interior dessa grande sacerdotisa. (MÃE..., 1986).

Note-se que, ao descrever a personalidade da famosa ialorixá, D. Timóteo acaba deixando as impressões digitais da sua própria, tendo em vista essa rara capacidade, patente em ambos, de "autoimolar-se" por sua tradição ancestral sem aprisioná-la a "determinismos limitadores", mas assumindo-a com "liberdade e amor" em um projeto de futuro que a faz gerar "mais ser", na fecunda cumplicidade criadora com os mo(vi)mentos do tempo - isto é, esse enraizamento da energia libertadora humana no imo "imemorial" da tradição, mais acima indicado como posição "transmoderna" da espiritualidade timoteana.

Os laços fraternos de D. Timóteo com Mãe Menininha se estendem a outras importantes mães-de-santo da Bahia, como Mãe Senhora do Ilê-Axé-Opô-Afonjá - a quem é apresentado pelo antropólogo iniciado Vivaldo da Costa Lima -, sua sucessora Mãe Stella de Oxóssi e Olga de Alaketu, do Terreiro da Casa Branca. A cumplicidade do abade com o Povo de Santo é selada com a sua participação na comissão que lutou pelo tombamento do Terreiro da Casa Branca como patrimônio histórico nacional, ante a ameaça iminente de expropriação pela Shell para construção de um posto de gasolina no local. Em sinal de confiança e gratidão, D. Timóteo é sagrado ogã, sendo convidado com frequência a participar de festas litúrgicas somente acessíveis aos iniciados no culto dos orixás.

O candomblé se baseia na experiência que o homem tem do cosmos, da natureza em que ele vive sua vida, e nessa natureza ele enxerga poderes que vêm do axé. O modo como Deus age para produzir um efeito salvador chama-se teologicamente 'economia da salvação'. Então, a religião 'cósmica' é uma economia válida e, por isso, deve ser extremamente respeitada, em nome do respeito à consciência. Ao mesmo tempo, eu percebi no mundo do candomblé um grande respeito. Eles não pensavam em me aliciar e me converter, não vejo neles nenhum trabalho de proselitismo. Não, um grande respeito! Muita conversa, muito acolhimento, muita alegria e muita beleza na celebração entusiástica, muito ligada à vida. A hospitalidade, o poder de acolhimento muito carinhoso, muito generoso. Uma coisa belíssima! (TAVARES, 1995, p. 216-217, grifo do autor).
Marcando distância em relação a uma teologia salvacionista cristocêntrica plantada no regime medieval de Cristandade a reboque da romanização do cristianismo, a qual projeta na figura do Deus exclusivo e excludente a pulsão de poder de uma Igreja imperial, D. Timóteo Amoroso ratifica a participação da espiritualidade do candomblé na "economia divina de salvação" na precisa medida em que ela trabalha pela libertação do ser humano, com sua efusão de alegria, hospitalidade, beleza, encontro, carinho e generosidade.

A relação com o candomblé inaugura o diálogo fraterno de D. Timóteo Amoroso com pessoas de outras religiões, igrejas, crenças ou sem profissão de fé, ao longo de seu apostolado na Bahia, a exemplo de judeus, protestantes, budistas, adeptos de crenças New Age, ateus, agnósticos. Com base em larga experiência ecumênica, inquire seus pares de fé: 'Não somos também nós 'crentes demais', ao rejeitarmos os 'estranhos' (de raça, ideologia, de crença, de interesse), como se o Livro da Vida tivesse de coincidir pura e simplesmente com as estatísticas religiosas e as listas de membros das associações católicas?” (ANASTÁCIO, 1990, p. 186, grifo do autor).

Com o recrudescimento da repressão, em face das notícias de prisões, torturas, desaparecimentos e deportações, antes "solicitado pelos acontecimentos e pessoas" (ANASTÁCIO, 1989, p. 16) do que por um claro programa político, D. Timóteo Amoroso aproveita-se do pouco espaço deixado às autoridades eclesiásticas e, não obstante a intimidadora cortina de silêncio que se instala, começa a desencadear uma série de denúncias e ações contra a ditadura militar:

Então, eu não medi limites para falar, seja na igreja seja quando a imprensa ainda podia publicar as coisas e aquilo também foi crescendo a minha própria consciência da dor horrível que há na supressão da liberdade, uma sociedade também de ódio, onde só a anistia é que pode reaver os laços dos cidadãos entre si. (ANASTÁCIO, 1989, p. 16).

Revisitando antiga tradição beneditina durante as guerras feudais, abriga nas dependências do Mosteiro militantes clandestinos ou foragidos. Neste capítulo da parte épica de sua história, o episódio mais conhecido é o refúgio dado às pressas a um 
grupo de manifestantes estudantis perseguidos a tiros pela polícia, a qual invade o Mosteiro em seu encalço e obriga o abade ao embaraço canônico de precisar recolher os estudantes à segurança do claustro, até o dia seguinte, inclusive as moças, apesar de expressa proibição da Regra. Aturdido com a grave transgressão autorizada pela autoridade maior da comunidade, um piedoso ancião da Ordem, às lágrimas, pede que D. Timóteo assine uma declaração ao Papa admitindo a própria excomunhão, mas o abade o tranquiliza com palavras do Evangelho: "A lei foi feita para o homem, não o homem para a lei." (ANASTÁCIO, 1989, p. 20). Intervém junto a autoridades públicas pela libertação de presos políticos e denuncia as torturas na imprensa, fato a que o militante comunista Haroldo Lima atribui não ter sido morto, pois, ao saberem das denúncias, os torturadores de imediato passaram a abrandar suas ações quando estas chegavam ao extremo do insuportável. A fim de abrir uma brecha na "situação monolítica", D. Timóteo passa a dirigir um jornal clandestino intitulado " $\mathrm{O}$ Círculo", mimeografado no próprio Mosteiro, que servia de subsídio para militantes de comunidades populares do Nordeste, enquanto um grupo no Rio de Janeiro o distribuía para o Sudeste e Sul do País. Dado o perigo iminente de invasão do Mosteiro para apreensão do material, a publicação foi suspensa e a coleção de exemplares, destruída. No auge da repressão, ante a brutal desproporção das forças em disputa, D. Timóteo chega a compreender e apoiar a guerrilha armada como recurso extremo dos que lutavam contra o regime de exceção, chegando a invocar a autoridade teológica do Doutor Comum da Igreja para avalizar sua ousada posição:

Vendo com todo horror a ação repressiva que se endurecia e que se tornava cada vez mais cruel, pelos testemunhos que a gente recebia, não foi difícil eu passar para o sentimento de que realmente não havia outra saída senão a luta armada, porque um governo ditatorial não entrega espontaneamente os pontos. Ele realmente se defende porque aquilo é toda uma acumulação até de orgulho, de vontade, de gozo do poder, de domínio sobre o homem e de manipulação do homem. Você tem que ter respeito às pessoas e um certo controle para que isso não seja uma obra de ódio, que seja uma forma de amor. Mas não tenho dúvida que a própria doutrina da Igreja, oficialmente, com Santo Tomás de Aquino, admite a revolução para derrubar o tirano. (ANASTÁCIO, 1989, p. 19).

O monge contemplativo, cuja vocação amadurecera no silêncio do claustro, é agora instado a recorrer ao barulho para não se omitir em face de vidas em perigo. O obediente filho da Ordem, em cujo seio foi educado para o sentido sapiencial da tradição e da autoridade, doravante é incitado à dessacralização profética de toda ordem que, ao invés de servir ao ser humano, dele se serve para manter o próprio poder. D. Timóteo desperta, assim, para a dimensão transgressora da fé cristã, em cujo centro situa-se um Deus-Humano banido pelo poder político e religioso, que "pôs em questão a situação concreta da época, as estruturas e os costumes de então, a 'boa consciência' e a segurança dos que absolutizavam a segurança e a 'boa ordem'." (ANASTÁCIO, 1990, p. 126, grifo do autor). Dócil aos ventos que impelem os eventos da história e movimentam a sua própria consciência, D. Timóteo afinal chega à dimensão pública intrínseca à fé cristã, indo ao encontro da "teologia política" já em curso na vanguarda do pensamento cristão:

As promessas divinas de justiça, paz, reconciliação, liberdade etc., não podem ser 'privatizadas', isto é, não podem ficar circunscritas à esfera particular, pois são, em si, realidades eminentemente sociais e públicas. Importa, pois, que os cristãos se empenhem com toda força na vida pública do país, ao lado de todo ser humano de boa vontade, que também esteja comprometido com a justiça, a paz, o bem do povo. (ANASTÁCIO, 1990, p. 111, grifo do autor).

Nessa perspectiva, cabe aos cristãos contribuir para transformar a ordem sociopolítica em favor da promoção da dignidade dos que nela se encontram oprimidos e excluídos, e não meramente adaptar-se a suas estruturas que, em geral erguidas pelo poder de uma minoria privilegiada e mantidas por inércia, tendem a reproduzir a injustiça em escala coletiva. Tal tensão entre ordem social e transgressão profética vem à baila por ocasião da polêmica em torno da inscrição do nome de Deus no texto da Constituição de 1988, a que se opunha o deputado comunista Haroldo Lima, alegando a laicidade do Estado republicano e a impropriedade de invocar o nome de Deus sobre uma ordem sociopolítica baseada no desigual acesso aos direitos. Concor- 
dando com a posição do amigo ateu, na contramão da rumorosa maioria dos cristãos, o abade de São Bento assim pondera:

Um deputado ou senador cristão ou de qualquer religião deve, evidentemente, colocar-se 'sob a proteção de Deus' e querer tudo fazer em seu 'nome' se é coerente com a sua fé. Mas uma lei é secular e universal e se destina, como é o caso da Constituição, a ordenar uma sociedade laical e pluralista, não devendo, por isto, conter nenhuma alusão confessional. Para nós cristãos, a Constituição será uma confissão de Deus, se for inspirada na justiça e na dignidade do homem. É na consciência disto, que nos distinguiremos dos ateus, e não em afirmações, por mais respeitáveis que sejam, gravadas nos textos civis. O piedoso costume de incluir o nome de Deus na Constituição pertence a regimes de religião oficial, o que não acontece na República. E bem sabemos que, malgrado a boa intenção que levou as monarquias 'cristãs' a esse gesto de reverência, o resultado se tornou equívoco. (NETO et al., 1996, p. 16, grifo do autor).

Em 1968, quando a "ordem" militar no Brasil atinge seu nível mais repressivo com a promulgação do Ato Institucional $\mathrm{n}^{\circ} 5$, que fecha o Congresso Nacional e suspende garantias constitucionais, realiza-se em Medellín, Colômbia, a Segunda Conferência Geral do Episcopado Latino-Americano. $\mathrm{Na}$ esteira do Concílio Vaticano II e de toda a fermentação profética das comunidades eclesiais de base latino-americanas, Medellín declara, pela primeira vez na História da Igreja, a "opção preferencial pelos pobres", constituindo revolucionária "tomada de consciência da Igreja como sendo uma Igreja dos pobres comprometida com a libertação do Continente em face de sua dependência cultural às potências do Norte." (ANASTÁCIO, 1989, p. 21). Neste mesmo ano, D. Timóteo Amoroso faz imprimir na tipografia do Mosteiro o documento "Ouvi os Clamores de meu Povo", assinado por ele com outros religiosos e bispos da CNBB, no qual a opção preferencial pelos pobres é reiterada em contexto brasileiro, com todas as consequências aí implicadas, em claro repto dirigido aos militares.

Em nível teórico, a experiência eclesial de base consignada em Medellín encontra sua clarividente tradução na Teologia da Libertação, que interpela a Revelação a partir do rosto desfigurado do pobre assumido como lugar hermenêutico, e dirige-se à sua realidade desfigurada, com o auxílio analítico das ciências sociais, para transfigurá-la à luz da Boa Nova libertadora da Revelação. A inserção de D. Timóteo Amoroso nas fronteiras dos trabalhos eclesiais de base acabaria por propiciar-lhe fecundo diálogo com alguns notáveis teólogos da libertação, como Frei Betto e, em especial, Leonardo Boff, precursor de expressão mundial.

Já com atualizado respaldo teológico, ao lado de padres, religiosas e leigos(as), no início da década de 1970 D. Timóteo Amoroso forma o grupo "Moisés", sediado no Mosteiro de São Bento e no Centro de Estudos e Ação Social (CEAS) dos jesuítas, que visava articular organizações sociais do meio popular e apoiar a resistência política por meio de intervenções públicas ainda viáveis no restrito contexto. Pouco mais tarde, acolhe no espaço do Mosteiro o Trabalho Conjunto, integrado por entidades civis comprometidas com a liberdade e os direitos humanos. Ente os quadros que despontam no Trabalho Conjunto, destaca-se a militante de esquerda Lídice da Mata, cuja campanha para prefeita de Salvador, em 1992, contra o candidato do então governador da Bahia Antônio Carlos Magalhães, teria o apoio público do já encanecido abade de São Bento. (ANASTÁCIO, 1989).

Em 1979, a Terceira Conferência Geral do Episcopado Latino-Americano, ocorrida em Puebla, México, reafirma a opção preferencial pelos pobres assumida em Medellín, e dá um passo à frente ao propor a superação do secular contexto de opressão a partir de um novo sistema social definido como de "comunhão e participação". (ANASTÁCIO, 1990). Com aprovação do Grupo Moisés, D. Timóteo envia aos bispos em Puebla um documento de subsídio de alta contundência profética, no qual apresenta sem rebuços uma série de "denúncias" dentro e fora da Igreja. Dentre outras mazelas, indigita a mentalidade e estruturas eclesiais de dominação, elitismo teológico e sacramental, autoritarismo eclesiástico e burocracia palaciana, dicotomia fé-justiça; e, em âmbito social, cita o alto custo de vida, baixos salários, desemprego, precárias condições de trabalho (sobretudo de jovens e mulheres), expulsão da terra, falta de liberdade e de participação política e social, utilização de tortura etc. Em face das "esperanças históricas" do povo em libertação, propõe aos bispos o apoio 
a movimentos populares do campo e das periferias urbanas, defesa da anistia ampla e irrestrita a todos os presos políticos, apoio a religiosos "enxovalhados" por assumirem a causa dos injustiçados, desligamento nítido "dos que apoiam, em nome da religião e do progresso, o sistema capitalista e suas maléficas consequências", e a escuta da sabedoria do povo simples. (ANASTÁCIO, 1990, p 103-105):

Estamos convencidos de que soou a hora do Espírito, e de que é só neste Espírito, que Puebla terá êxito e sentido para os povos da América Latina e da Igreja universal. E o que diz o Espírito às nossas Igrejas, senão que é impossível a fé sem a luta pela justiça e pelos direitos dos homens? E que a Igreja não será fiel à sua missão se não se puser resolutamente a serviço do povo e assim exprimir a sua fé no Cristo Libertador encarnado na história e vivo na sua Igreja. (ANASTÁCIO, 1990, p. 103).

Com respaldo das Conferências Episcopais, toma impulso na América Latina uma pastoral dos Direitos Humanos de amplo espectro, que tem por base teológica a sacralidade da dignidade humana, cuja violação constitui, à luz da fé cristã, uma afronta ao próprio Deus. (ANASTÁCIO, 1990). A partir da maturação de sua reflexão teológica, porém, D. Timóteo Amoroso alcança o entendimento de que o horizonte profético-utópico da fé cristã não se limita à luta pela libertação integral da vida humana, mas abrange a sacralidade da vida em si mesma, por toda parte ameaçada pela imposição global de um mesmo sistema civilizatório cientificista-tecnocrático-capitalista que a tudo reduz a objeto de manipulação, produção, uso, consumo, enfim, lucro. Nessa perspectiva, D. Timóteo realça dois aspectos da crítica cultural à "intervenção danosa da tecnologia": o conceito meramente funcional de natureza, à qual já não se reserva qualquer "respeito" ou "reverência"; e a "fé ilimitada" no progresso técnico, a ignorar o senso de medida e equilíbrio, caindo na espécie de desmesura espiritual que os gregos esconjuravam com o nome de hybris. Ora, as coisas, por mais humildes, portam "a dignidade do ser e do existir" e, "embora senhor da natureza, o homem não tem sobre elas um direito absoluto nem arbitrário, mas responsável." (ANASTÁCIO, 1990, p. 44-45). Assim, o pensamento de D. Timóteo chega a formular a compreensão do meio ambiente como "morada comum" e "bem social", antecipando em duas décadas categorias basilares da Encíclica Laudato Si, do Papa Francisco, afinada com o que há de mais ousado no pensamento ecológico atual:

A interconexão dos fatos que se passam na biosfera permite afirmar que há uma unidade da biosfera. Assim, o agir de cada pessoa individual ou do grupo, num determinado lugar, traz consequências mais vastas, às vezes até mesmo planetárias (veja-se a Amazônia) e até mesmo a notável distância do tempo. O ambiente é um bem eminentemente social. Não basta denunciar o assalto à natureza, apenas porque é um atentado à 'nossa' vida. Pois o homem é somente um elemento a mais - embora senhorial e régio - no grande cosmos de Deus. E a ecologia, que nasceu como ciência do equilíbrio entre o homem e a criação, transforma-se, dentro de uma visão mais ampla, naquilo que um autor espiritual chama de 'ecosofia', isto é, uma sabedoria de relacionamento entre tudo o que existe. (ANASTÁCIO, 1990, p. 93, grifo do autor).

\section{Conclusão: o monge atravessado pela experiência}

Como o personagem Riobaldo de Grande Sertão: Veredas, seu conterrâneo das Minas, D. Timóteo Amoroso provou o perigo intrínseco ao correr da vida. Ao se provar e descobrir a cada nova experiência, do cometa incandescente à mulher-estrela, do êxtase contemplativo no deserto monástico ao êxodo profético nas periferias da história, deixou-se atravessar pela experiência; fez-se homem-travessia. Tendo se aventurado, às últimas consequências, no tempo como dimensão de evento - como abertura àquilo "que vem" -, D. Timóteo abriu mão de medir a vida por certezas prévias e identidades pré-moldadas para fazer da existência a permanente disponibilidade à visitação do novo, a morada da epifania. Orfeu afinado ao diapasão do mistério, no coração do tempo foi encontrar o Deus que dança - como exigia Nietzsche,$-{ }^{10}$ e dançou ao seu vário ritmo:

Deus emite na sua flauta uma música delicada que só quer escuta para que haja a dança da obediência, para que a vida do ser humano se transforme numa verdadeira dança alegre, feliz e cheia de surpresas.

10 "Eu só poderia crer em um deus que soubesse dançar". 
Nós transformamos a nossa vida numa espécie de 'ordem unida' militar, 'um, dois, um dois', quando muito fazendo ginástica, mas Deus está tocando uma música que convida à dança, e dançar com Deus é realmente viver a experiência, a aventura do imprevisível, do belo. Quando você dança, você não precisa saber aonde vai, é o ritmo que vem da música que leva. Não é um programa que você fez, mas a fidelidade do ouvido à música que toca. (ANASTÁCIO, 1990, p. 13, grifo do autor).

Transido por tal senso de abertura e provisoriedade, de epifania em epifania, D. Timóteo Amoroso veio a encontrar na vida monástica um irresistível apelo a recolher-se ao centro mais profundo de si mesmo, como se aí the fosse dado viver a experiência radical que the comunicaria, no secreto do silêncio, o sentido de todas as experiências possíveis. Não busca, portanto, no Mosteiro a fortaleza de reservas arqueológicas a salvo dos assaltos do tempo, mas o deserto que lhe permitiria despojar-se dos haveres acessórios para abeirar-se das fontes eternas de sentido em que tudo se decifra e se unifica, e cuja seiva sustenta a obra de renovação do próprio tempo. Prova da vitalidade da experiência monástica de $\mathrm{D}$. Timóteo é que, quando os ventos dos eventos da segunda metade do século XX o arrebatam em plena vida monacal, ele não recua ao claustro em regressão uterina, mas é o próprio caldo sapiencial do humanismo cristão que lhe dá a necessária perspectiva para ler os acontecimentos da história em chave profética e aventurar-se em seu curso como fermento de libertação, seja pela via do engajamento social mais solidário, da luta política mais revolucionária ou da mais criadora inculturação no seio da tradição popular. Assim, é o recolhimento ao pertencimento que lhe dá propulsão para a travessia histórica; é a radicalidade da vertente sapiencial de sua espiritualidade que lhe permite ir tão fundo, e além, na coragem de sua vertente profética. Por haver guardado, cioso, o tesouro de sua matriz sapiencial, soube colaborar com maior eficácia para o nascimento do humano na história.

Nessa paideia transmoderna de inspiração cristã, maturada ao longo de sua vida e obra, reside a maior contribuição do pensamento timoteano ao desafio civilizatório da contemporaneidade. Mais que uma época de agudas mudanças, a contempo- raneidade configura uma mudança de época na qual distintos vetores históricos se cruzam e tencionam, abrindo um ambíguo espectro de oportunidades e perigos a exigir delicado discernimento. ${ }^{11}$ De um lado, a exacerbação "hipermoderna", levando ao extremo a energia expansiva/emancipatória da modernidade, destitui qualquer legitimação de posições passadistas reativas, mas também periga exaurir-se na hybris do progressismo; de outro lado, a desagregação "pós-moderna" abre fissuras alvissareiras na hegemônica ordenação econômica-técnica-jurídica edificada na modernidade, cujo vigor emancipatório acabou sendo subsumido por projetos de dominação, mas deriva na multiplicação metastática de jogos de linguagem e modas, e na reiteração autista de identidades indiferentes entre si. Seja pelo estéril progressismo hipermoderno ou pelo autofágico relativismo pós-moderno, $\mathrm{o}$ coração vertiginoso da contemporaneidade reclama uma fonte sapiencial que lhe dê sentido, medida, eixo gravitacional. Fontes sapienciais de sentido, porém, não são passivas de produção; não resultam de cálculo e projeto: dão-se ao encontro a partir de paciente fundo ancestral que, brotando de profundezas imemoriais do tempo e dirigindo-se ao ser humano de cada época em sua própria língua, solicita a escuta - a memória - do que não pode ser descurado sem que o humano venha a desfigurar-se.

As fontes sapienciais são tantas quanto inesgotável é o sentido que lhes cabe transmitir, e D. Timóteo Amoroso veio encontrar a sua na tradição monástica beneditina, de matriz judaico-cristã. Mesclada a elementos espirituais gregos, a tradição monástica incuba um legado formativo que, ademais de gerar vasto cabedal de conhecimentos nas mais diversas áreas, contribuindo com a base do futuro saber universitário, compreende uma filosofia de vida baseada na sujeição à transcendência divina, no diálogo de fé e razão, no senso da dignidade inviolável da pessoa humana e na ética da justiça. Trabalhada no recolhimento contemplativo, a paideia monástica consubstancia um potente substrato humanista cuja atualidade permanece viva. No entanto, circunscrita à civilização ocidental greco-europeia, e sob influxo da Cristandade, ela acaba enviesada por uma mentalidade

11 Sobre o conceito de contemporaneidade e sua articulação com a proposta de uma racionalidade transmoderna, ver Santos (2013). 
colonizadora apoiada em racionalismo abstrato e dualista, da qual escapam aspectos essenciais do humano que somente virão à tona com a irrupção da modernidade ou já em plena contemporaneidade, como razão crítica, percepção da desigualdade de classes, relação de política e ética, diferença cultural - e diálogo intercultural -, valorização da cultura popular, e unidade espírito-corpo.

Desinstalado pela experiência de sucessivos acontecimentos históricos, D. Timóteo Amoroso é impelido a descobrir a nova face da fé cristã, para além dos resíduos de Cristandade ocidental ainda em vigor na instituição monástica. De dentro do Pai espiritual nasce, então, o Profeta, engajado, revolucionário, inculturado, encarnado, para o qual a salvação divina comunicada ao ser humano passa por sua libertação integral aqui e agora. Do molde clássico da paideia monástica, cristã-ocidental, de caráter eminentemente formador, afloram, então, em seu percurso formativo os sinais de uma nova paideia, cristã, latinoamericana e contemporânea, fiel aos princípios eternos mas enraizada na cultura do povo e aventurada na história, tão formadora quanto transformadora. Se tal transfiguração tem evidente efeito rejuvenescedor sobre a espiritualidade monástica, em contrapartida também mostra, ante os caminhos cruzados da contemporaneidade, que a memória do eterno alarga os horizontes utópicos da história, e o livre pertencimento à fonte sapiencial da tradição, ao invés de subjugar a liberdade humana, contribui para libertá-la de suas aporias. Segundo o espírito dessa nova paideia, portanto, a fidelidade às fontes sapienciais de sentido se prova e renova na abertura à energia emancipatória dos novos tempos, a qual, por sua vez, torna-se tanto mais libertadora, e até libertária, quanto mais profunda é a sua ligação às fontes sapienciais de sentido.

\section{REFERÊNCIAS}

A BÍBLIA de Jerusalém. São Paulo: Paulinas, 1986.

ANASTÁCIO, D. Timóteo Amoroso. Revista da Bahia, Salvador, n. 12, março de 1989.

A Flauta de Deus. Salvador: Empresa Gráfica da Bahia, 1990.

ANASTÁCIO, D. Timóteo Amoroso; SAJA, José Antônio. Propter Fratres Meos - Discurso por ocasião da outorga do Título de Doutor Honoris Causa pela Universidade Federal da Bahia. Salvador: Empresa Gráfica da Bahia, 1990.

JAEGER, Werner. Paideia. Tradução de Artur M. Parreira. 2. ed. São Paulo: Martins Fontes, 1989.

MÃE Menininha. A Tarde, Salvador, 20 ago. 1986.

NETO, Joviniano. et al. D. Timóteo: presença histórica. Salvador: Edufba, 1996.

OTTO, Rudolf. O sagrado. Tradução de Walter O. Schlupp. Petrópolis, RJ: Vozes, 2007.

SANTOS, Luciano Costa. O pensamento fecundo: elementos para uma racionalidade transmoderna. Revista da FAEEBA: Educação e Contemporaneidade, Salvador, v. 22, n. 39, p. 205-213, jan./jun. 2013.

O cristianismo transmoderno: fé cristã e literatura brasileira contemporânea. In: AGUADO, Maria Eugenia L.; SANTOS, Luciano Costa; CONTRERAS, Humberto Silvano H. (Org.). Cultura e fé: um olhar pastoral interdisciplinar. Brasília: CNBB, 2014. p. 5-132.

TAVARES, Eduardo Diogo. O milagre de Dom Amoroso - ou como D. Timóteo, abade do Mosteiro de São Bento, venceu as legiões hereges. Salvador: P\&A, 1995.

Recebido em: 24.02 .2016

Aprovado em: 24.05.2016 